\title{
THE ROMANIAN AGRICULTURE - BETWEEN MYTH AND REALITY
}

\author{
Cristian - Marian Barbu ${ }^{l}$
}

\begin{abstract}
This paper analyses the performance of the Romanian agriculture as against the EU agriculture from a historic perspective in order to reveal the gaps and to demythologize the assertion saying that „Romania has been Europe's most productive cereal-producing agriculture”. The findings resulted from the survey based on data provided by Eurostat - the Statistics of the European Commission, by national statistics and various national and international publications show that the Romanian agriculture has been, in its historical evolution, in a European marginal zone from the point of view of economic performance and has not been able to ensure food security and increased export of value added agricultural products, while the global demand is much higher than the supply and some EU countries have reached their maximal productivity.
\end{abstract}

Key words: performance, gaps, trade, most productive cereal-producing agriculture, vegetal agricultural production

JEL Codes: N50, O13, Q10

\section{Introduction}

Food security has been always a national priority for the rich countries which encouraged the creation and the use of various supporting measures for agriculture and protective measures for farmers.

The macroeconomic context where agriculture and rural communities developed in Romania was the result of political and strategic measures taken on short term, most of them, and included agriculture and its social area as marginal topic. Keeping marginal the rural communities and labeling them as traditional and conservatory built an obstacle in understanding a world that had its own evolution and knew how to preserve social authenticity and normality (Gavrilescu and Giurcă, 2000).

In terms of dimension and structure, as well as functionality, the Romanian rural area has a major importance for the national territory.

Romania, as a result of its accession to the European Union on $1^{\text {st }}$ of January 2007, entered the Common Agricultural Policy (CAP), specific of the European Union, without having a national basic strategy; which explains why today, the Romanian agriculture is far from having the agricultural competitiveness of the other EU member states. There is a deficit in the trade with agricultural products while the agricultural potential of our country is still neglected and the concept of food security is totally ignored.

The place of agriculture in the economy of a country depends on the role it can have in economic development. The Romanian agriculture has always been in a marginal area, during its evolution, from this point of view of economic performance.

This paper analyses the performance of the Romanian agriculture as against the EU agriculture from a historic perspective in order to reveal the gaps and to demythologize the assertion saying that „Romania has been Europe's most productive cereal-producing agriculture”. Like all legends, we don't know who and when created the phrase „Romania, most productive cerealproducing European agriculture" although it still circulates without being supported by historic

\footnotetext{
${ }^{1}$ „Artifex” University, Bucharest, Romania, e-mail: barbu_cristianmarian@yahoo.com
} 
realities. The 1861 historical annals, during the reign of Alexandru Ioan Cuza, in an article on the greatest assets of the country, said that Romania has the potential to become the „most productive cereal-producing agriculture in Europe". The phrase was later on taken over until the $1^{\text {st }}$ World War began by the big owners of farms who pleaded in favour of their lands and claimed that had turned Romania into the most productive agriculture in Europe. Following the agricultural reform in 1921 which was the most radical in Europe and distributed an average of 4 hectares of land per family, thus transforming the big land properties into small properties and small farms, with extremely low efficiency, between the two world wars 1919-1939, the claim that „Romania - was the most productive agriculture in Europe" weakened; however, some publications, authors and parliamentarians, in their discourse, took over and disseminated this phrase without paying the slightest attention to statistics which contradicted this theory. This legend became lethargic for half a century between 1945-1989, when the economic policies were based exclusively on the Communist doctrine (Marxist-Leninist and Soviet) implying a fair ratio (s.n.) between industry and agriculture. "The Communist fairness" was motivated as follows: agriculture was the main sector while industry was the priority to develop national economy since development of agriculture, constructions, transportation (...) was the direct result of the country's industrialization (Giosan, Ceauşescu and Gheorghiu, 1983). After the 1989 Revolution, taking advantage of the people's ignorance, the legend was brought back to life and circulated again, enjoyed credibility, and it was taken over by the media since its dissemination was an argument for certain causes and actions of the politicians or authorities.

Given these aspects, we shall present statistical data in this article so that to measure accurately the Romanian agricultural production and export of cereals and to place Romania in the European context.

\section{Literature review}

Since economy was restructured, agriculture became, after 1990, the main income source for a significant percentage of the population, thus paying a safety net role for the laid off people or people who could not find a job. Subsistence or semi-subsistence agriculture has become thus a feature of the rural Romanian area (Alexandri and Luca, 2008; Giurcă, 2008).

Romania is a EU recent member with a significant agricultural potential. This potential is not sufficiently used because of: excessive fragmentation of agricultural lands, ageing of the active population, use of inappropriate technologies, insufficient funds and low agricultural management (Burja and Burja, 2010). Consequently, the Romanian agriculture is mainly a subsistence agriculture with a low competitiveness on the EU market and a deficit in the trade with food products. The analysis based on the Eurostat data revealed the low performance of the Romanian agriculture as against the EU member states agricultures, in terms of production and labour productivity (Burja, 2011). The economic transition undergone by Romania strongly affected the rural population (Sandu, 1999; Heller, 2000; Schrieder, 2000; Horvath, 2008), which was affected more than the urban population by poverty, unemployment, lack of high quality public services, all this resulting into precarious living conditions for many rural inhabitants. Economic restructuring led to new social forms like subsistence agriculture and extreme poverty, unknown before 1989. The large scale subsistence agriculture meant self-adapting of the poorest population to the new economic conditions and one of the main surviving strategies under the circumstances. The subsistence and semi-subsistence agriculture are often defined as farming activities performed by the peasant on small plots of land with rudimentary means for the purpose of the household consumption. The economic literature in the field highlights three significant criteria to define the subsistence agriculture: the area of the farm, the production and the extent to which the products are sold on the market (Giurcă, 2008, p. 216).

After being supported from public funds to reach high performance and stability, the agriculture of the advanced EU member states is seen as an industry. There are still concerns 
regarding the variation of the agricultural production depending on the climate changes, the volatility of the agricultural prices under the pressure of the search for alternative energy sources (Von Braun, 2008) and speculative actions (Zawojska, 2010). In the EU, synchronization of the business cycle in the EU member states is a pre-requisite to efficiently enforce the joint policies but significant differences between the new member states and the old member states diminish synchronization (Da-Rocha, 2006).

The current state of the Romanian agricultural economy and its basic structures, as against the other EU member states, has been the topic of the research done by a team of researchers from : the Research Institute for Agricultural Economy and Rural Development of the „Gheorghe Ionescu - Siseşti" Academy for Agricultural Sciences and Forestry in Bucharest, the Academy for Economic Studies and the Institute for Agrarian Economy of the National Institute for Economic research of the Romanian Academy in their sectoral project financed by the Ministry of Agriculture and Rural Development and entitled: „Study on the impact of accession upon producers and consumers" (Zahiu, Dachin and Alexandri, 2010).

\section{Research methodology}

In order to reach our objective, we have used fundamental research methods consisting in reading of the specialized literature in this field and some articles and studies covering this topic.

In order to establish and analyse the state and the performance of the Romanian agriculture in the European context and from the historical perspective, we have used the data provided by the European Commission (Eurostat, for instance) and by national statistics and by various national and international publications that we assessed and interpreted. Our methods have been: analysis, synthesis, comparison, deduction and induction.

\section{Results and discussion}

Agriculture has traditionally been a major Romanian economic sector. This belief has objective but also strong subjective motivations as it is part of the collective mythology of the Romanian people.

According to a European comparative statistics published in Lemberg in 1865, the production of cereals in Romania was worth 115 million French francs and the export of cereals was $31 \%$ of the production meaning 36 million French francs. At that time, the cereal-exporting European countries were sending cereals worth 573 million francs to the rest of the European countries. Russia and Poland covered together $42 \%$ of the European cereal export, the Ottoman Empire exported cereals that were worth 84 million francs, Austria exported cereals that were worth 62 million francs, Denmark exported cereals that were worth 52 million French francs and the German Customs Union (set up in 1819) exported cereals that were worth 36 million francs. The value of the Romanian cereal exports was therefore $6.28 \%$ of the total exports of the European countries. At the same time, many European countries were importing cereals that were worth 811 million French francs while Romania covered about $4.4 \%$ of the overall cereal import in Europe. We can infer that Europe had at that time a cereal commercial deficit of 238 million francs (importing 811 million francs and exporting 573 million francs), and this deficit was covered with imports from the other side of the Atlantic. Consequently, with $6.28 \%$ of the European export and $4.4 \%$ of the European import, Romania could not be in the years 1870 s the cereal procurement source for Europe so it was far from being the ,most productive cereal-producing agriculture in Europe".

The Romanian agriculture has incurred remarkable progress between 1860-1915 when the export of cereals increased from 568,000 tons which was the average amount for 1862-1866, to $1,925,000$ tons which was the average of 1909-1913, representing an increase of 3.39 times. At that time, Romania achieved 5\% of the total cereal production in Europe, $6.4 \%$ of the wheat production and $18 \%$ of the maize production. Romania contributed with 2.9 million tons, that is $13.4 \%$ of the 
total export of cereals in Europe which was 21.6 million tons. On the other hand, Romanian covered $8.7 \%$ out of the 33.2 million tons of cereals imported in Europe. The total consumption in Europe (production plus import minus export) was 132.6 million tons of cereals to which Romania contributed with (domestic consumption plus export) 6.2 million tons of cereals which meant $4.7 \%$ of the consumption of cereals in Europe. Since the statistical data are the following: $5 \%$ of the production of cereals in Europe, $13.4 \%$ of the export of cereals, $8.7 \%$ of the import of cereals in Europe and providing only $4.7 \%$ of the consumption of cereals in Europe, Romania could not be the „most productive cereal-producing agriculture in Europe” before the $1^{\text {st }}$ World War.

During the two world wars, 1919-1939, after the 1921 agrarian reform, as a result of destructuring the big land properties (latifundia) that were providing most of their production of cereals for export, and their turning into small land properties, Romania lost its place in the top of production of cereals and export of cereals in Europe before the $1^{\text {st }}$ world war. One of the most important effects of the fragmentation of the agricultural land was the diminished productivity per hectare with $25-30 \%$ less in various cultures and diminished agricultural quality with impact upon competitiveness of the cereals on the world market. At this time, the population increased with 2.7 times, and the production per inhabitant diminished to $62.3 \%$ of the previous level that is with over a third as against 1909-1913, while consumption increased with only $1 \%$. The reduced production affected only the Romanian export of cereals which diminished with $82 \%$.

The 1930 agricultural census revealed that Romania had an agricultural land of about 19.8 million hectares, out of which the arable land was about 12.9 million hectares and the structure of the land property was as follows:

Table no. 1

Structure of the agricultural land property in Romania in 1930

\begin{tabular}{|c|c|c|c|c|}
\hline $\begin{array}{c}\text { Type of } \\
\text { property }\end{array}$ & $\begin{array}{c}\text { Number of } \\
\text { properties }\end{array}$ & $\begin{array}{c}\text { Area owned by } \\
\text { each type }\end{array}$ & $\begin{array}{c}\text { Weight in total number } \\
\text { of properties - \% - }\end{array}$ & $\begin{array}{c}\text { Weight in total } \\
\text { agricultural land - \% - }\end{array}$ \\
\hline 1-10 ha & 3 millions & 9.5 millions ha & $92 \%$ & $48 \%$ \\
\hline 10-50 ha & 235 thousands & 3.9 millions ha & $7.2 \%$ & $19.8 \%$ \\
\hline over 50 ha & 25 thousands & 6.4 millions ha & $0.8 \%$ & $32.2 \%$ \\
\hline
\end{tabular}

1938 saw the highest development of national economy; progress was seen also in 1939, especially in economic sub-sectors or industries connected to army procurement and army orders caused by the overall defense policies of the state. In 1938, the national revenue was 4.5 times higher than in 1862, and the income per capita was 76 dollars. In the 8 decades of capitalist development, significant changes took place. Although in 1938 Romania was still a country with an agrarian-industrial economy, as against the advanced countries, and the mechanized industry was not fully developed, the structure and the contribution of the main sectors of economy to the national revenue significantly changed as against 1862. While in 1862 the agriculture represented $70 \%$ and the industry and the constructions only $10 \%$ to the national revenue, in 1938 the agriculture represented only $38.5 \%$, while industry, constructions and transportation had $42 \%$ of the national revenue. To note that there was an over-population in the rural areas with $76.5 \%$ of the total active population as against $11.5 \%$ in industry or $12 \%$ in trade, banks and finance. Industry had a structure that was unilaterally developed and unequally distributed in the basic sectors: metallurgy, energy, production of machines and tools, petro-chemical sector. In terms of structure, level and economic development, Romania had the same situation as the neighbouring countries: Yugoslavia, Hungary, Poland, Greece and a bit better than Bulgaria, Turkey, and Albania. As a country with a significant agriculture but poor technical level, Romania produced a lot of agricultural products, ranking the $5^{\text {th }}$ among the wheat-producing countries in Europe and the $1^{\text {st }}$ maize-producing country. However, despite the myth regarding the export capacity of Romania which would have turned it into the ,most productive agriculture in Europe”, the agricultural 
production exported between 1936-1938 was much lower than between the two world wars, with only 1.8-2 million tons.

According to the data included in the International Annuary of Agricultural Statistics, between 1934-1938, the average produced in Europe was 126.3 millions tons of cereals, out of which Romania produced 10.5 million tons, which means 8.3\%. At that time, Europe exported 10.9 millions tons of cereals per year and imported 41.4 million tons per year. Romania provided $14.7 \%$ of the export in Europe and 3.9\% of the import. The consumption of cereals in Europe was 157.1 million tons, Romania provided about $6.6 \%$, that was 10.3 million tons. The statistics abovementioned prove undoubtedly that during its modern history, Romania, although it had an agriculture-based economy or, at least, mainly, agriculture-based one, and one of the highest production of cereals in Europe (80-90\% of the total arable area), it did not objectively have the capability to provide a huge amount of cereals for Europe to be considered one of the main sources of cereals in Europe.

During 1950 - 1989, when the forced setting up of agricultural-cooperatives generated big agricultural farms, and massive investments brought chemicals and mechanical tools in agriculture, over a third of the arable land had agricultural irrigations (almost 3 million hectares of arable land had irrigations in 1989, out of the total of 9.4 million hectares of arable land), which increased the productivity per hectare, the Romanian cereal supply to the European market was still low. The evolution and the trends of the foreign trade exchanges between Romanian and other countries between 1950-1989 were affected by various circumstances, by the traces of the war, both economic and political, by the national production factors, by the global economic environment, by prices and domestic and global economic policies. Before concluding, it is to note that the value of the export and the import during that time is reflected by the 1990 Statistic Annuary of Romania which gives some methodological clarifications. The value of the goods exported and imported was computed starting from the FOB prices (free on board) for each year, expressed in lei-foreign currency for the period 1950-1980, and in lei starting with 1981. The conversion of the foreign currencies into lei for the period 1950-1980 was done according to the official exchange rate of the National Bank of Romania for each period of time taken into account and the conversion into lei for 1981-1989 was done according to the market exchange rate for each year. The commercial balance of Romanian had a deficit between 1950-1980, and a surplus between 1981 - 1989 (see table no 2).

Table no. 2

Commercial balance of Romanian between 1950-1989

\begin{tabular}{|c|c|c|c|}
\hline Years & Export & Import & Difference \\
\hline \multicolumn{3}{|c|}{ millions lei foreign currency } \\
\hline 1950 & 1,274 & 1,461 & -187 \\
\hline 1960 & 4,302 & 3,887 & +415 \\
\hline 1970 & 11,105 & 11,761 & -656 \\
\hline \multicolumn{5}{|c|}{ millions lei } \\
\hline 1980 & 50,963 & 59,006 & $-8,043$ \\
\hline 1985 & 178,031 & 147,023 & $+31,008$ \\
\hline 1986 & 163,989 & 135,781 & $+28,208$ \\
\hline 1987 & 167,850 & 132,984 & $+34,866$ \\
\hline 1988 & 182,258 & 122,263 & $+59,995$ \\
\hline 1989 & 167,780 & 134,982 & $+32,798$ \\
\hline
\end{tabular}

The statistical data reflecting the trends of exports and imports of Romania between 19501989 lead to the following conclusions:

- Regarding exports, the weights of the raw materials for the production of food products and of the food products are similar; at the beginning of this period, in 1950, relatively significant weights, the first of $11.6 \%$ and the latter of $14.1 \%$, and at the end of the period, in 1989 , only $0.6 \%$ 
and $4.3 \%$ respectively. Both in absolute and relative values, there was a descending slope after 1980, which can be explained by the diminished agricultural production after 1985 when some agricultural products were controlled. Among the exported food products, the most significant amounts were the meat and the meat-related products, edible vegetal oil, butter, various types of cheese, eggs, vegetables and canned vegetables, fruit and canned fruit, sugar and sugar-based products, wine, honey etc. The raw materials exported were wheat and maize, bovine, ovine and pigs for to be taken to slaughterhouses, tobacco, spices and others.

- Regarding imports, the weights of the raw materials for the production of food products was $0.7 \%$ in 1950 and $1.7 \%$ in 1989, and the weight of food products was $0.3 \%$ in 1950 and $1.5 \%$ in 1989. Among the most important food products imported in low amounts: ocean fish and fish-based products, rice, citrus fruits, coffee, cacao, olives, edible oils.

Briefly, the land according to its destination and the probable population in the rural area that was active in agriculture between 1918-1989 in Romania are presented in tables no 3 and no 4.

Table no. 3

Structure of land in Romania according to its destination between 1918-1989

\begin{tabular}{|c|c|c|c|c|c|c|}
\hline \multirow{2}{*}{ Period } & \multirow{2}{*}{ Total } & \multicolumn{3}{|c|}{ Agricultural area } & \multicolumn{2}{c|}{ Non-agricultural area } \\
\cline { 3 - 7 } & Arable & $\begin{array}{c}\text { Hayfields and } \\
\text { pastures }\end{array}$ & $\begin{array}{c}\text { Vineyards } \\
\text { and } \\
\text { orchards }\end{array}$ & Forestry & Other areas \\
\hline $1919-1924$ & 29,505 & 11,477 & 4,972 & 458 & 6,525 & 6,073 \\
\hline $1935-1939$ & 29,505 & 13,706 & 4,711 & 600 & 6,367 & 4,121 \\
\hline 1960 & 23,800 & 9,820 & 4,201 & 525 & 6,403 & 2,851 \\
\hline 1980 & 23,800 & 9,834 & 4,467 & 663 & 6,337 & 2,499 \\
\hline 1989 & 23,800 & 9,458 & 4,705 & 596 & 6,372 & 2,669 \\
\hline
\end{tabular}

Table no. 4

Probable population in rural area active in agriculture between 1918-1989

\begin{tabular}{|c|c|c|c|c|c|}
\hline Year & unit & Total & $\begin{array}{c}\text { Total active } \\
\text { population }\end{array}$ & $\begin{array}{c}\text { Population in rural areas } \\
\text { (out of the total population) }\end{array}$ & $\begin{array}{c}\text { Active rural population } \\
\text { (out of the total active } \\
\text { population) }\end{array}$ \\
\hline \multirow{2}{*}{1920} & $\begin{array}{c}\text { thousands } \\
\text { inhabitants }\end{array}$ & 15,541 & 9,076 & 12,088 & 7,102 \\
\cline { 2 - 6 } & $\%$ & 100.0 & 58.4 & 77.8 & 78.3 \\
\hline \multirow{2}{*}{1939} & $\begin{array}{c}\text { thousands } \\
\text { inhabitants }\end{array}$ & 19,934 & 11,534 & 16,312 & 78.026 \\
\hline \multirow{2}{*}{1989} & 100.0 & 57.9 & 81.8 & 3,050 \\
\hline
\end{tabular}

As a continuation of the genuine crisis of the efficacy of allocating resources which had begun before 1989, the transition years witnessed low performance of the farmers. Historically, one of the main features of the Romanian agriculture is the low productivity in the use of the land. The average productions per hectare have been always lower than other European productions. In terms 
of productivity per hectare and performance of zootechnical production, Romania ranked among the lowest in Europe between 1938-1989, when the economic and social evolution of the country incurred radical changes, and it still holds this position (table no 5). These productivities lead to the following conclusions:

- While in all EU countries, the cereal production per hectare (average of the years) increased from one period to another, (with several exceptions), Romania had a threefold increase between 1988-1990 as against 1934-1938, and a decrease between 1999-2001 as against 1988-1990;

- The absolute gaps increased between 1988-1990, as against 1934-1938, in most countries that are currently EU members. Romania managed however to have better results than Finland, Spain and Portugal, and diminished its relative gaps as against all countries except for France and Greece;

- Between 1999-2001, as against 1988-1990, the absolute gaps increased in all EU countries except for Portugal, as against Romania; the relative gaps that had diminished during the centralized economy, increased in all EU countries including Portugal.

Table no. 5

Cereal production per hectare in Romania, as against other European countries

\begin{tabular}{|c|c|c|c|c|}
\hline \multirow[b]{2}{*}{ Country } & \multirow[b]{2}{*}{ PERIOD } & \multirow{2}{*}{$\begin{array}{c}\text { AVERAGE OF } \\
\text { THE YEARS } \\
\text { ( kg/ha) }\end{array}$} & \multicolumn{2}{|c|}{ Gaps as against Romania } \\
\hline & & & $\begin{array}{c}\text { Absolute } \\
\text { Kg/ha }\end{array}$ & $\begin{array}{c}\text { Relative } \\
\text { Romania }=1\end{array}$ \\
\hline \multirow{4}{*}{ Romania } & 1934-1938 & 921 & 0 & 1.00 \\
\hline & $1988-1990$ & 3,109 & 0 & 1.00 \\
\hline & $1999-2001$ & 2,678 & 0 & 1.00 \\
\hline & $2007-2009$ & 2,453 & 0 & 1.00 \\
\hline \multirow{4}{*}{ Belgium } & 1934-1938 & 2,615 & $+1,694$ & 2.84 \\
\hline & $1988-1990$ & 6,238 & $+3,129$ & 2.01 \\
\hline & 1999-2001 & 8,244 & $+5,566$ & 3.08 \\
\hline & $2007-2009$ & 9,350 & $+6,897$ & 3.81 \\
\hline \multirow{4}{*}{ Ireland } & 1934-1938 & 2,417 & $+1,496$ & 2.62 \\
\hline & $1988-1990$ & 6,169 & $+3,060$ & 1.98 \\
\hline & $1999-2001$ & 7,062 & $+4,384$ & 2.63 \\
\hline & $2007-2009$ & 8,320 & $+5,867$ & 3.39 \\
\hline \multirow{4}{*}{ France } & 1934-1938 & 1,461 & +540 & 1.59 \\
\hline & $1988-1990$ & 6,101 & $+2,992$ & 1.96 \\
\hline & $1999-2001$ & 7,082 & $+4,404$ & 2.64 \\
\hline & $2007-2009$ & 7,197 & $+4,744$ & 2.93 \\
\hline \multirow{4}{*}{$\begin{array}{l}\text { United } \\
\text { Kingdom }\end{array}$} & 1934-1938 & 2,145 & $+1,224$ & 2.33 \\
\hline & 1988-1990 & 5,792 & $+2,683$ & 1.86 \\
\hline & 1999-2001 & 6,850 & $+4,172$ & 2.56 \\
\hline & $2007-2009$ & 7,810 & $+5,357$ & 3.18 \\
\hline \multirow{4}{*}{ Germany } & 1934-1938 & 2,169 & $+1,248$ & 2.36 \\
\hline & $1988-1990$ & 5,715 & $+2,606$ & 1.84 \\
\hline & 1999-2001 & 6,737 & $+4,059$ & 2.52 \\
\hline & $2007-2009$ & 7,620 & $+5,167$ & 3.11 \\
\hline \multirow{4}{*}{ Denmark } & 1934-1938 & 2,626 & $+1,705$ & 2.85 \\
\hline & $1988-1990$ & 5,646 & $+2,537$ & 1.82 \\
\hline & $1999-2001$ & 6,114 & $+3,436$ & 2.28 \\
\hline & $2007-2009$ & 7,487 & $+5,034$ & 3.05 \\
\hline \multirow{4}{*}{ Austria } & 1934-1938 & 1,604 & +683 & 1.74 \\
\hline & $1988-1990$ & 5,407 & $+2,298$ & 1.74 \\
\hline & 1999-2001 & 5,732 & $+3,054$ & 2.14 \\
\hline & $2007-2009$ & 5,133 & $+2,680$ & 2.09 \\
\hline \multirow{4}{*}{ Sweden } & 1934-1938 & 2,056 & $+1,135$ & 2.23 \\
\hline & 1988-1990 & 4,333 & $+1,224$ & 1.39 \\
\hline & $1999-2001$ & 4,537 & $+1,859$ & 1.69 \\
\hline & $2007-2009$ & 6,153 & $+3,700$ & 2.51 \\
\hline
\end{tabular}




\begin{tabular}{|c|c|c|c|c|}
\hline \multirow{4}{*}{ Italy } & 1934-1938 & 1,605 & +684 & 1.74 \\
\hline & $1988-1990$ & 3,816 & +707 & 1.23 \\
\hline & 1999-2001 & 4,895 & $+2,217$ & 1.83 \\
\hline & $2007-2009$ & 3,603 & $+1,150$ & 1.47 \\
\hline \multirow{4}{*}{ Greece } & 1934-1938 & 897 & -24 & 0.97 \\
\hline & 1988-1990 & 3,306 & +197 & 1.06 \\
\hline & 1999-2001 & 3,266 & +588 & 1.22 \\
\hline & 2007-2009 & 2,597 & +144 & 1.06 \\
\hline \multirow{4}{*}{ Finland } & 1934-1938 & 1,567 & +646 & 1.70 \\
\hline & 1988-1990 & 3,016 & -93 & 0.97 \\
\hline & 1999-2001 & 3,076 & +398 & 1.15 \\
\hline & 2007-2009 & 3,853 & $+1,400$ & 1.57 \\
\hline \multirow{4}{*}{ Spain } & 1934-1938 & 1,079 & +158 & 1.17 \\
\hline & 1988-1990 & 2,669 & -440 & 0.86 \\
\hline & 1999-2001 & 2,966 & +288 & 1.11 \\
\hline & $2007-2009$ & 3,193 & +740 & 1.30 \\
\hline \multirow{4}{*}{ Portugal } & 1934-1938 & 778 & -143 & 0.84 \\
\hline & 1988-1990 & 1,659 & $-1,450$ & 0.53 \\
\hline & 1999-2001 & 2,558 & -120 & 0.96 \\
\hline & $2007-2009$ & 1,947 & -506 & 0.79 \\
\hline
\end{tabular}

Source: Gh. Dobre et al., Economia României în context European - 1938, The Publishing House of the "Memoria Oeconomica", Scientific Foundation, Bucharest, 1996, p. 192; Constantin Grigorescu et al., Nivelul dezvoltării economico-sociale a României în context European 1989, Expert Publishing House, 1993, p. 71-72; our own calculation for 1999-2001, based on the Romanian Statistic Annuary, INS, 2003 and the Czech, Hungarian, Latvian, Lithuanian, Polish, Romanian, Slovakian and Slovenian Agriculture in Comparison with EU Countries, table no 4.1.1.4., IERIGZ, Poland, Warsaw, 2003; our own calculation based on Eurostat for 2007-2009.

At all times, therefore - between the two world wars, during the centralized economy, during the transition towards the market economy as well as at present - the cereal productivity per hectare ranked Romania behind the countries that are nowadays EU members, with a few exceptions, already mentioned, and gaps deepened, which meant a serious handicap in the process of EU accession.

About $30 \%$ of the EU population live in the rural area but only $4-5 \%$ of the active population work in agriculture which means that most adults living in rural areas do not earn their living by working the land. Moreover, the weight of agriculture in the EU GDP is only $1.5-2 \%$. In Romania, $45 \%$ of the population lives in the rural areas; out of the 9.2 millions active persons, $45 \%$ are active in the rural area (4,208,000 persons) and about $28 \%$ are active in agriculture out of which more than a million are unpaid family workers. The weight of agriculture in the GDP is 6-7\% in Romanian as against other EU countries, like Poland and Hungary which have 4\%. Although the figures are not proportionate with the European average, they are not a concern.

According to a Eurostat report, Romania has about 3.9 million farms of various dimensions. The problem arises when we want to analyze the structure of these farms and their economic sustainability. The statistic data make us worry: out of the 3.9 million households, about 2.5 million own under 1 hectare and only 900,000 have the minimal economic productivity( 1 ESU). However, out of the 900,000 'profitable' farms, two thirds produce only for their own consumption. Out of the 3.9 million of Romanian farms, only 312,000 , that is $8 \%$, are economically viable and connected to the market (especially big agro-industrial farms), while the rest of $92 \%$ are subsistence households. Moreover, the population working in agriculture is old, the farmers who are 50 - 70 years old have $2,330,083$ hectares of the total agricultural land and less than $8 \%$ of the active population in agriculture is under 35 years old. Behind what we may call "over-sized Romanian agriculture" there is hidden poverty. The majority of the 2 million Romanians who, according to the statistics, are (pseudo)farmers live in poverty or below poverty and they are all potential emigrants. This already visible effect can be called the "tragedy of the Romanian village". Far from turning into a modern farmer, the Romanian peasant gradually disappears and takes away with him the chance of a healthy agriculture. 
Table no. 6

Farms in Romania in 2010

\begin{tabular}{|c|c|c|c|c|c|}
\hline \multirow{2}{*}{ Sizes } & \multicolumn{2}{|c|}{ Number farmers } & \multirow{2}{*}{$\begin{array}{l}\text { Area } \\
\text { - ha - }\end{array}$} & \multirow{2}{*}{$\begin{array}{c}\text { Weight } \\
-\% \text { - }\end{array}$} & \multirow{2}{*}{$\begin{array}{c}\text { Average size of } \\
\text { the farm } \\
\text { - ha - }\end{array}$} \\
\hline & Nr. & $\%$ & & & \\
\hline $1-10$ ha & $1,087,853$ & 93.7 & $3,000,720.74$ & 31.25 & 2.95 \\
\hline $10-100$ ha & 61,182 & 5.3 & $1,580,530.10$ & 16.47 & 25.80 \\
\hline Over 100 ha & 11,994 & 1 & $5,018,822.24$ & 52.28 & 418.40 \\
\hline Total & $1,161,029$ & 100.0 & $9,600,073.08$ & 100.00 & 8.83 \\
\hline
\end{tabular}

(according to APIA data - Agency for Payments and Intervention in Agriculture; APIA is subordinated to the Ministry of Agriculture, Forestry and Rural development under the Law no 1/2004 with further modifications and completions)

According to APIA data (Agency for Payments and Intervention in Agriculture), as against the previous years, the number of farmers owning between 1-10 ha diminished with $3 \%$, and the area owned by them diminished with $3.5 \%$. At the same time, the number of farms owning between 10-100 ha increased with $2 \%$ and the area increased with $5.8 \%$.

The vegetal agricultural production in Romania increased in 2010 as against 2009 in: cereals for seeds, leguminosae for seeds, oily plants, sugar beetroot, and fruits, and decreased in: potatoes, vegetables and grapes, according to the National Institute of Statistics (INS). In 2010, the production of cereals for seeds increased with $11.4 \%$, to 16.57 million tons, as against 14.87 million tons in 2009, because of the higher productivity per hectare (average production per hectare) with $17.2 \%$ in oats, $15.8 \%$ in wheat and $11.1 \%$ in barley and two-row barley. According to the Eurostat data, the production of cereals in the EU (UE-27) in 2010 was about 281 million tons; the Romanian production of cereals of 16.57 million tons is only 5.9\% out of this production which objectively shows once more that Romania does not possess the capability to provide a huge amount of cereals to Europe to be considered one of the main sources of cereals in Europe.

Romania cultivated cereals in 2010 on about 5 million de hectares, maize for seeds on $44.3 \%$ of this area and wheat on $40.7 \%$. Last year, the wheat production was 5.59 million tons, maize for seeds was 9.1 million tons, the production of barley and two-row barley was 1.32 millions tons, and the production of oats was 328,000 tons. There was an increase of $19 \%$ productivity per hectare in maize for seeds and the total production increased with $14.2 \%$. The production of leguminosae increased with $9.4 \%$ last year as against 2009, to 58,000 tons, because of the average production per hectare, while the area cultivated remained the same. The production of oily plants increased with $29.8 \%$, to 2.29 million tons, as a result of increasing the area cultivated with $40.7 \%$ and of the increased productivity per hectare. There were also increased productions of soya (73.8\%), to 146,000 tons, colza $(62.1 \%)$, to 924,000 tons and sunflower (15.2\%), up to 1.26 million tons. The sugar beetroot increased with $4.4 \%$ as against 2009 , that is to 853,000 tons, mainly because or a higher productivity per hectare, while the area cultivated remained the same. The potato production decreased with $17.5 \%$, that is to 3.3 million tons, because of the reduced productivity per hectare and smaller areas cultivated, the vegetable production decreased with $7.7 \%$ to 3.6 million tons because of small areas cultivated with $6.4 \%$. The production of bell peppers decreased with $8,9 \%$, to 224,000 tons, the production of onion decreased with $6,9 \%$ to 352,000 tons, the production of cucumbers decreased with $6,8 \%$ to 164,000 tons, the cabbage decreased with $4,6 \%$ to la 956,000 tons, the tomatoes decreased with $2,4 \%$ to 738,000 tons and the carrots decreased with $1,4 \%$ to 212,000 tons. The production was higher in watermelons and melons with $1.1 \%$, up to 660,000 tons. In 2010 , the production of grapes decreased to 737,000 tons as against 2009 mainly because of smaller areas cultivated with grafted grapevines with $2.1 \%$ and with hybrid grapevines with $2.2 \%$. The productivity per hectare was lower with $6.6 \%$ as against 2009 . The production of fruits in orchards increased with $30.2 \%$ as against 2009 up to 910,000 tons. Per type of fruit, the production increased in plums with $70.3 \%$ up to 424,000 tons, cherries and sour cherries with $29.2 \%$ up to 31,000 tons, apricots with $28.6 \%$ up to 9,000 tons, apples with $8.4 \%$ up to 
411,000 tons and decreased in pears with $16.7 \%$ up to 20,000 tons. The areas cultivated with the main fruits decreased in pear-trees with $20.0 \%$ and apple-trees with $1.9 \%$ and remained the same in plum-trees, cherry-trees and sour cherry-trees, and apricot-trees as against 2009. According to the Eurostat data for 2010, the EU diminished the areas cultivated, the productions and the productivities for some basic cultures.

In terms of area cultivated with wheat, Romania ranked the $4^{\text {th }}$ in the EU in 2010 , and the $7^{\text {th }}$ in production because of the productivity of $51.2 \%$ which meant half of the average productivity in the EU. In terms of area cultivated with maize, Romania ranked the $1^{\text {st }}$ in the EU and the $2^{\text {nd }}$ in production after France because of a lower productivity. The productivity in maize in Romania is lower (except for Bulgaria) than in the other EU member states. In terms of area cultivated with sunflower, last year Romania ranked the $1^{\text {st }}$ in the EU and the production of sunflower in Romania ranks the $3^{\text {rd }}$ after France and Bulgaria, because of the productivity lower with $14.1 \%$ as against the average productivity in the EU. In terms of area cultivated with potatoes, Romania ranks the $3^{\text {rd }}$ after Poland and Germany, and the $6^{\text {th }}$ in production after Germany, Poland, Holland, France and United Kingdom because of a lower productivity of only $56.3 \%$ of the average productivity in the EU.

The Romanian export of agricultural products and food products increased with $40 \%$ in 2010 up to 3.06 billion euro, as against 2.18 billion euro in 2009, while imports increased with $2 \%$, from 3.71 billion euro to 3.78 billion euro, according to the data of the Ministry of Agriculture and Rural Development (MADR). Thus, Romania exported in 2010 agricultural products and food products of 2.24 billion to EU countries as against 1.68 billion euro in 2009, and in terms of exports to other countries than EU, they were worth 823.2 million euro in 2010 as against 499.9 million euro in 2009.

In 2010, Romania imported agricultural products and food products from EU countries of 3.06 billion euro, as against 2.98 billion euro in 2009 and imported agricultural products and food products from other countries than EU whose value was worth 720.6 million euro in 2010 as against 731.12 million euro in 2009.

The EU is Romania's main trade partner in agricultural products. In 2010, exports to the EU represented $73 \%$ and imports from the EU represented $80.9 \%$, according to the data provided by the Ministry of Agriculture and Rural Development (MADR).

Most exports in 2010 were represented by maize, of 2.05 million tons and worth 388.3 million euro, wheat and maslin (a 2 to 1 mixture of wheat with oats), which represented 2.48 million tons exported and worth 379.44 million euro, followed by paper cigars and cigars $(20,616$ tons worth 377 million euro). In 2010, Romania exported over 1.05 million tons of colza seeds (worth 334.04 million euro) and 557,409 tons of sunflower seeds (worth 214.8 million euro); also 51,810 tons of bovine animals were exported (worth 98.8 million euro), 771,877 tons of barley (worth 94.92 million euro), 178,084 tons of sugar from sugar-can sugar beetroot (worth 89.98 million euro), 44,741 tons of ovine or caprine animals (worth 86.6 million euro) and 58,580 tons of poultry meat worth 81.5 million euro.

Most significant imports in 2010 are pork, with 198,914 tons and worth 304.7 million euro, sugar from sugar-can of sugar beetroot with 465,653 tons worth 216.24 million euro, oil-cakes and other waste resulted from soya oil extraction with 435,214 tons worth 132.54 million euro, poultry meat with 93,528 tons worth 114.95 millions euro, wheat and maslin with 719,954 tons worth 112.44 million euro. In 2010, Romania imported 208,284 tons sunflower seeds worth 109.72 million euro, 38,283 tons coffee worth 108.39 million euro, 117,549 tons refined sunflower oil and saffron oil worth 98.09 million euro, 430,548 tons of maize worth 89.43 million euro, 33,337 tons of chocolate and other cacao-based products worth 97.47 million euro. 


\section{Conclusions}

Agriculture played a major role in the development of society since old times. The new paradigm of sustainable growth emphasizes the role of agriculture in economic growth, in ensuring food security, in poverty reduction, in the reduction of income disparities, in the development of the rural area and environmental protection (Byerlee et al., 2009).

Although Romania ranks the $7^{\text {th }}$ in the EU after France, Spain, Germany, Great Britain, Poland and Italy in terms of agricultural land used, there are significant discrepancies in terms of the weight of agriculture in the GDP between Romania and the EU member states, and between the incomes of the farmers, their living standards, the investment possibilities, the development prospects for agriculture. In order to fulfill its functions, agriculture must develop according to economic principles; there should be social and environmental performance, which imply efficient use of both available and attracted resources. Economic performance means efficiency in a certain system, it is not merely a comparison between effect and effort (Burja, 2011).

Since less than $8 \%$ of the population active in agriculture is under 35 , given the excessive fragmentation of the agricultural land (there are about 3.9 million farms), which caused more inhouse consumption and, implicitly, low profitability, the big farms of over 100 ha represent only $1 \%$ of the total of farms that own more than 1 hectare, and since most farms cultivate cereals which have the lowest productivity in the EU, it is hard to imagine that Romania could soon meet the food needs of its own citizens.

The evolution of a wide range of farms is currently going into a vicious circle: the lack of economic performance generates lack of resources to form capital and the lack of capital continues and amplifies the low economic performance. Unable to compete with the EU products, the Romanian agriculture has only time for survival.

Statistics clearly show that, because of excessive fragmentation of the agricultural land, of the huge number of persons active in agriculture and because of the mainly manual nature of the production processes resulting into low productivity, Romania has never been able and will not be able to become the best cereal-producing source in Europe, or, as the legend says, the „most productive cereal-producing agriculture in Europe", but it still remains in a marginal European zone.

\section{References}

1. Alexandri C., Luca L., 2008. Romania and CAP reform, Agricultural Economics and Rural Development, no 3-4/2008, pp.161-180

2. Barbu C.-M., 2006. Politici şi strategii în susținerea agriculturii prin mecanismul plăţilor directe din bugetul comunitar, ARTIFEX Publishing House, Bucharest

3. Barbu C.-M., 2005. Posibile politici de susținere a dezvoltării durabile a agriculturii şi a spațiului rural în Romania, Matrix Rom Publishing House, Bucharest

4. Byerlee D., de Janvry A., Sadoulet E., 2009. Agriculture for Development: Toward a New Paradigm, Annual Review of Resource Economics, Vol. 1, pp. 15 -31

5. Bozga V., Puia I.., Vasile R., Ribczuc E., 1993. Istoria economiei naționale/ History of the national economy, Bucharest

6. Burja V., 2011. Regional disparities of agricultural performance in Romania, Annales Universitatis Apulensis Series Oeconomica, 13 (1), pp. 115-121

7. Burja C., Burja V., 2010. Sustainable value analysis for Romanian agriculture, Environmental Engineering and Management Journal, June, Vol.9, No.6, pp. 839-846

8. Da-Rocha J. M., Restuccia D., 2006. The role of agriculture in aggregate business cycles, Review of Economic Dynamics, vol. 9, issue 3, 2006, pp. 455-482 
9. Gavrilescu D., Giurcă D. (coord.)., 2000. Economie Agroalimentară, Expert Publishing House in co-edition with Biotera Publishing House, Bucharest, pp. 360

10. Giosan N., Ceauşescu I., Gheorghiu M., 1983. Agricultura socialistă a României, Political Publishing House, Bucharest, pp.79

11. Giurcă D., 2008. Semi-subsistence Farming - Prospects for the Small Romanian Farmer to choose between a way of living or efficiency, in „Agricultural Economics and Rural Development", nr. 3-4, pp. 215-230

12. Heller W., 2000. Socioeconomic transformation in rural Romania through the eyes of experts: demographyc and social issues, in „GeoJournal”, vol. 50, pp. 151-155

13. Horvat I., 2008. The Culture of Migration of Rural Romanian Youth, in „Journal of Ethnic and Migration Studies", vol. 34, no. 5, pp. 771-786

14. Irimiea M., 2005. Istoria economiei naționale, UPG Publishing House, Ploieşti

15. Josan A., 2004. Economia României interbelice în context european, ASE Publishing House, Bucharest

16. Josan A., 2004. Evoluții economice pe plan mondial în perioada interbelică, ASE Publishing House, Bucharest

17. Mureşan M., 2004. Istoria economiei, $2^{\text {nd }}$ edition, Economic Publishing House, Bucharest

18. Mureşan M., 1995. Evoluții economice: 1945-1990, Economic Publishing House, Bucharest

19. Olaru C., 1999. Istoria Economiei. Prelegeri, ASE Publishing House, Bucharest

20. Oprițescu M., 2001. Economia în Principatele Române: 1829-1866, Economic Publishing House, Bucharest

21. Saizu I., Tacu Al., 1997. Europa economică interbelică, Institutul European, Iaşi

22. Sandu D., 2005. Romania rurală neagricolă. Sociologie Românească, 3, 4, pp. 76-108

23. Sandu D., 1999. Dezvoltare şi sărăcie în satele Românei. Sociologie Românească, no 4, 1999, pp. 117-138

24. Schrieder G., Munz J., Jehnre R., 2000. Rural Regional Development in Transition Economies: The Case of Romania, în „Europe-Asia Studies”, vol. 52, 7/2000, pp.1213-1235

25. Sută N., Drăgan G., Mureşan M., Sută S., 1996. Istoria comerțului exterior românesc, Eficient Publishing House, Bucharest

26. Von Braun J., 2008. Rising food prices: what should be done, IFPRI Policy Brief, available online at http://www.ifpri.org/pubs/bp/bp001.pdf

27. Zahiu L., Dachin A., Alexandri C.(coord.), 2010. Agricultura în economia României - Între aşteptări şi realităţi, CERES Publishing House

28. Zawojska A., 2010. Speculative drivers of agricultural price volatility and food insecurity, The 119th Seminar of EAAE "Sustainability in the Food Sector: Rethinking the Relationship between the Agro-Food System and the Natural, Social, Economic and Institutional Environments", Capri, Italia, 30 June - 2 July 2010, http://www.centroportici.

29. unina.it/EAAE_Capri/papers/Session10/Zawojska.pdf

30. National Institute of Statistics - Statistic Annuaries.

31. Eurostat database, available at http://epp.eurostat.ec.europa.eu/portal/page/portal /agriculture /data/main_tables. 